\title{
Affluence Threat: \\ Property Norms and Police Brutality in The United States
}

\author{
Brendan Szendrő \\ PhD Candidate, Political Science \\ Binghamton University
}

Over the course of recent years, the United States has become increasingly conscious of police violence against racial minorities. Videos documenting killings of black men by police routinely show no violence on the part of the victims. Widespread public awareness has grown to the notion that police may disproportionately target racial minorities (Lowery, 2016). At the same time, a number of controversial studies have attracted attention and scrutiny suggesting that these disparities can be explained through other means. Such studies typically suggest that crime rates relative to racial categories have greater explanatory power than race itself (Johnson et al, 2019); others that avoid such arguments still struggle to link race to Fatal Interactions with Police, or FIPs (cf. Delahanty et al, 2017; Lawson Jr., 2018). What, then, explains the discrepancy between the facts on the ground and these apparent empirical findings?

I argue that these studies lack historical, institutional and cultural context. They ignore both the dynamics of police violence as well as the history of repression that underlies divisions between neighborhoods. To explain FIPs from this angle, I introduce the concept of "affluence threat," based loosely on Blalock's $(1957 ; 1967)$ power-threat theory. In effect, this refers to the threat perceived by wealthy interests in the presence of competition from lower economic strata. As with the literature on racial threat, affluence threat suggests that reactions exist where distinct classes live in proximity (Tigges \& Tootle, 1993; Cohen, 1998; O'Connell, 2012). Due to racial sorting - the division of racial groups into distinct living conditions - racial minorities disproportionately inhabit socioeconomic categories that cast them as affluence threats.

Using county-level data, I seek to demonstrate that FIPs are higher where upper and lower economic strata coexist, as well as where racial minorities and whites coexist, and that these two phenomena heavily overlap. I build on earlier models by Helms \& Constanza (2019), Jacobs \& O'Brien (1998) and Gray \& Parker (2020) in using structural variables rather than individual characteristics. In this study, the authors argue that structural environments lead police to assess threats and respond accordingly with prior convictions. I theorize that such phenomena should become more apparent as property values rise, as the baseline value of property determines the so-called "stakes" that engender elite threat perception. I find that property values are linked to a higher number of FIPs; that both income inequality, as measured by GINI Coefficients, and the non-white population have quadratic relationships with FIPs; that both race and inequality have greater effects at higher property values; and finally, that the effect of inequality is dependent on the presence of race.

While existing data indicates that blacks are shot and killed by police at three times the rate of whites, studies of case-by-case shootings often find that when adjusting for 
other demographic factors and fixed effects, the racial disparities between police killings disappear (Fryer Jr., 2017; Cesario et al, 2018). These controversial studies have inflamed public debate in part because their inconclusive nature provided ammunition for unscientific arguments regarding structural inequalities between racial and class distinctions. They do not, however, do not account for the systematic divisions in opportunity between races in The United States, painting racism as a matter of individual opinion rather than a historic, institutional and cultural trend that may persist even as attitudes change. If it's the job of police is to uphold "order," that necessarily entails safeguarding institutions; if these institutions discriminate along the lines of class or race, they will shape the outcomes of policing regardless.

Put another way: engineered structural divisions in both social and economic capital between races - in particular, property ownership - will lead to disparities in police use of force, regardless of explicit racial bias in policing.

In order to tackle these issues, I first examine a broad array of historical facts and established critiques of policing to demonstrate the relevance of inequality and property ownership in American culture, as well as the history of race relations that directly plays into this distinction. Second, I discuss data operationalizing that can adequately demonstrate the interplay of these institutions. Finally, I use a series of statistical models to demonstrate a multistage phenomenon of racial sorting, affluence threat and FIPs.

\section{Property Ownership Norms}

Property ownership is both a norm and an ideal in The United States; historically, inequality was kept low through an abundance of land (Piketty 2013, pp. 150-152). Land was given as compensation for military service throughout early American history (Headle, 1922; Oberly, 1985). Although rates of home ownership have declined over the years, it remains a staple of the "American dream" (Shapiro, 2004). The role of land and property ownership in the American ethos was summed up in the film Gone With The Wind (1939), where one character opines "land is the only thing in the world worth working for, worth fighting for, worth dying for, because it's the only thing that lasts."

One enduring thesis cast land ownership as a frontier-based norm; these arguments noted that the abundance of land had led to the development of a distinct national ethos one that bred a spirit of competition. In the late nineteenth century, Frederick Jackson Turner (1921) suggested that "the American frontier is sharply distinguished from the European frontier - a fortified boundary line running through dense populations. The most significant thing about the American frontier is, that it lies at the hither edge of free land" (p. 3). Turner went onto suggest that:

“... the democracy born of free land, strong in selfishness and individualism, intolerant of administrative experience and education, and pressing individual liberty beyond its proper bounds, has its dangers as well as its benefits. Individualism in America has allowed a laxity in regard to governmental affairs which has rendered possible the spoils system and all 
the manifest evils that follow from the lack of a highly developed civic spirit. In this connection may be noted also the influence of frontier conditions in permitting lax business honor, inflated paper currency and wild cat banking" (p. 32).

One reason why such norms fostered a sense of competition is that agricultural work entails risk based on nature; poor weather, poor crop yields or loss of animal stock could render middle-class agricultural laborers penniless with little warning. This lent itself to a defensiveness in regard to property ownership. The loss of property would necessarily thrust such laborers under the thumb of creditors who might entrap them in lopsided contracts. Fears surrounding the loss of wealth may have generated informal honor codes leading to overzealous, violent vigilante behavior (Messner et al, 2005).

Still, agricultural norms provided mobility for commonly disparaged immigrant groups such as Irish who, facing a dearth of opportunity in major cities, used such norms as a means of obtaining mobility (Messner et al, 2005). Indeed, the original book from which Gone With The Wind was adapted speaks directly to the connection between Celtic immigrants and agrarianism, writing that "to anyone with a drop of Irish blood in them the land they live on is like their mother" (Mitchell 1936, p. 39). Once again, Turner's history keenly observed this phenomenon:

"The Revolutionary ideas, of course, gave a great impetus to democracy and in substantially every colony there was double revolution, one for independence and the other for the overthrow of aristocratic control. But in the long run the effective force behind American democracy was the presence of the practically free land into which men might escape from oppression or inequalities which burdened them in older settlements. This possibility compelled the coastwise States to liberalize the franchise; and it prevented the formation of a dominant class, whether based on property or on custom." (pp. 274-275).

The centrality of ownership to American economic mobility, however, must naturally raise the specter of race - in more ways than one. First, of course, because the original driving force behind this custom necessitated the removal of indigenous people from their lands. As westward expansion edged toward completion, Turner observed:

"This early recognition of the influence of abundance of land in shaping the economic conditions of American democracy is peculiarly significant to-day in view of the practical exhaustion of the supply of cheap arable lands open to the poor man, and the coincident development of labor unions to keep up wages" (p. 274).

It is also likely not a coincidence, then, that periods of opening former indigenous territory for settlement often immediately followed periods of sharp rises in inequality for example, the Dawes Act of 1887 fractured tribal lands (Stuart 1987, pp. 9-10). The passage of the law coincided with the initial burst of income inequality that would peak in the 1920s (Williamson 1987, pp. 51). American settlement often preceded military or 
government conquest (Billington \& Ridge 2001, pp. 26). In founding the reservation system, the American government claimed that it sought to protect the American Indians from "white land hunger" (Stuart 1987, pp. 70). In other words, ownership norms discriminated against Natives because white ownership necessitated a loss of indigenous sovereignty. Racism towards the indigenous people of the Americas often centered around their status as a foreign obstacle towards expanding America's monopoly on violence.

The second specter of race, the question of the black community, was more of a domestic matter. During his famous visits, Alexis de Tocqueville noted that "great equality existed among the emigrants who settled on the shores of New England. The germ of aristocracy was never planted in that part of the Union" while "in most states situated to the southwest of the Hudson some great English proprietors had settled, who had imported with them aristocratic principles and the English law of descent" (Tocqueville 1838, p. 29). He went onto add, "I know of no country where the love of money has taken stronger hold on the affection of men, and where the profounder contempt is expressed for the theory of permanent equality of property" (p. 33).

Although Tocqueville distinguished between the landed proprietors of the American south and the aristocrats of Europe, scholars since have not necessarily agreed. According to Moore (1966), the difference in political systems between north and south amounted to that between bourgeoise democracy and feudal aristocracy. Indeed, the main difference Tocqueville drew between the southern land owners and European aristocrats was that they in fact had less accountability because "the cultivation of their estates being carried on by slaves, they had no tenants depending on them, and consequently no patronage" (p. 29).

Racial anxiety has many roots in American history. One such root was the early American fear of slave revolts (Sharples, 2020). Thomas Jefferson, for example, initially expressed a willingness to embrace abolitionism despite his own investment in the institution of slavery. Over time, however, he faltered over a fear of "ten thousand recollections, by the blacks, of the injuries they have sustained" and "convulsions which will probably never end but in the extermination of the one or the other race" (Jefferson 1785 [1853], p. 149). Such sentiments on race worsened in tandem with the Haitian Revolution that ended in the mass execution of former slavers, and subsequent, small-scale revolts on American shores (Sharples, 2020). At the turn of the century, a slave revolt in Virginia aroused panic on the part of the slave-owning class. James Monroe, then the Governor of Virginia, wrote to Jefferson imploring his advice:

"There has been great alarm here of late at the prospect of an insurrection of the negroes in this city and its neighbourhood wh. was discovered on the day when it was to have taken effect. Abt. 30 are in prison who are to be tried on Thursday, and others are daily discovered and apprehended in the vicinity of the city. I have no doubt the plan was formed and of tolerable extensive combination, but hope the danger is passed. The trial will commence on thursday, and it is the opinion of the magistrates who examined those committed, that the whole very few excepted will be condemned" [sic] (Monroe, 1800a). 
Within a week, Monroe followed up without yet receiving a response. In this second letter, he outlined the threat posed by such revolts to wealth, property, and rule of law :

"It is unquestionably the most serious and formidable conspiracy we have ever known of the kind... While it was posible to keep it secret, wh. it was till we saw the extent of it, we did so. But when it became indispensably necessary to resort to strong measures with a view to protect the town, the publick arms, the Treasury and the Jail, wh. were all threatened, the opposit course was in part tak[en.] We then made a display of our force and measures of defence with a view to intimidate those people. Where to arrest the hand of the Executioner, is a question of great importance. It is hardly to be presumed, a rebel who avows it was his intention to assassinate his master... will ever become a useful servant" [sic] (Monroe, 1800b).

When Jefferson did at last respond, he did so cautiously. His answer sought to tread the fine line between his own investment in the system and the reality of its infeasibility:

"Where to stay the hand of the executioner is an important question... the other states \& the world at large will for ever condemn us if we indulge a principle of revenge, or go one step beyond absolute necessity. they cannot lose sight of the rights of the two parties, \& the object of the unsuccessful one. our situation is indeed a difficult one: for I doubt whether these people can ever be permitted to go at large among us with safety" [sic] (Jefferson, 1800).

Another was economic competition - amongst whites. By using a permanent enslaved underclass, wealthy white land owners could credibly promise poor and middleclass whites immunity from indentured servitude. As a result, agricultural laborers who did not personally own slaves had investments in the institution of slavery. In Tocqueville's observation, southerners had "have two powerful passions which will always keep them aloof; the first is the fear of being assimilated to the negroes, their former slaves; and the second, the dread of sinking below the whites, their neighbors" (p. 354).

Such prejudices did not only play out in the south, however. In the aftermath of abolition, northern states embraced segregation just as much as their southern counterparts. Efforts to separate the races spoke to the fear of loss of status; once again, Tocqueville acutely observed the logic behind this behavior:

"In the North the white no longer distinctly perceives the barrier which separates him from the degraded race, and he shuns the negro with the more pertinacity, since he fears lest they should some day be confounded together. Amongst the Americans of the South, nature sometimes reasserts her rights, and restores a transient equality between the blacks and the whites; but in the North pride restrains the most imperious of human passions. The American of the Northern States would perhaps allow the 
negress to share his licentious pleasures, if the laws of his country did not declare that she may aspire to be the legitimate partner of his bed; but he recoils with horror from her who might become his wife. Thus it is, in the United States, that the prejudice which repels the negroes seems to increase in proportion as they are emancipated, and inequality is sanctioned by the manners whilst it is effaced from the laws of the country" (pp. 339-340).

In the aftermath of the Civil War, newfound freedoms of the black community threatened to break up the white stranglehold on ownership. As a response to black social, political and economic mobility, white southerners began to engage in acts of vigilante violence. Southern vigilantism, typified in the popular conscious as lynching, could take on large-scale operations that included takeovers of city halls or forcing towns' entire black populations to flee (Brown, 1975; Ayers, 1984; Belew, 2014).

Vigilantism threatens government monopolies on the use of force (Davis, 2010; Gazit, 2015). Non-government actors maintain positions of relative power by catering to public wants that government does not fill (Berman \& Laitin, 2008). In the American south, vigilantism served to uphold a racial hierarchy anathema to the goals of southern reconstruction. For whites in southern governments, maintaining a monopoly on force meant absorbing the role of up-keeping racial hierarchy.

The historic role of policing in maintaining racial hierarchy is debated amongst historians and varies from place to place. From a pure "club public goods" model, it would follow that, in aggregate, government institutions would take on this mantle in places where enough demand existed that vigilantism retained a powerful presence.

It is difficult to pinpoint any one specific origin of a modern police force. Policing has its roots in both public and private institutions gradually merged into government auspices. Policing develops in stages starting with informal institutions, transitioning into modern types. This occurs at a highly regional level. In the American south, slave patrols may have played a role in transitioning from informal to modern policing (Reichel, 1988). In the aftermath of The Civil War, because slavery was permissible as punishment for crime, activities common amongst black communities became subject to increased scrutiny by law enforcement (Sellin, 1976).

Still, distinctions in law enforcement exist at every level of government, ranging from local to federal; histories of policing generally require a regional focus (cf. Reichel, 1988). In the north, police followed an English model of development; local neighborhood watch coexisted with private security forces. Municipalities integrated centralized forces as a means to consolidate control over cities; this occurred in distinct cities over a span of several decades (Mitrani, 2013).

Critiques from Marxist perspectives often stress the interests of property owners rather than public good. Centralized police forces came to exist to quell public disorder, much of which centered around clashes between non-owners and owners (Harring, 1983; Spitzer \& Skull, 1977). If this holds true, then the strength of capital should "set the stakes" 
for civilian-police interactions in the same vein as race or inequality. High stakes will result in Fatal Interactions with Police; high property values will indicate high stakes. Put succinctly,

\section{H1: As property values in a county increase, both the likelihood and number of FIPs increases.}

In some ways, this question of property values runs counter to traditional understanding of police brutality; images of aggressive policing tactics deployed against derelict neighborhoods. In actuality, the question of property paints a much deeper picture. One reason why gang activity proliferates in America's poorest neighborhoods is because they "occupy the vacuum created by the retreat of the social welfare policies of the state" linked to a "law and order trend [that] has targeted alienated and jobless African American youth, resulting in an unprecedented expansion of prison building" (Hagedorn, p. 154; 162). These such neighborhoods feature a lack of government monopoly on the use of force, meaning that police often avoid them. Rather, these tense interactions between civilians and police occur in places where different socio-economic strata coexist, in the shadow of wealth.

In relatively homogenous minority neighborhoods there is not much threat to be perceived. Relatively homogenous white neighborhoods should see less of a perceived threat as well, due to the tendency of entrenched elite classes to allow limited outsiders in as one of the so-called "good ones." Nominal relationships with underprivileged groups may serve as a form of social capital for elites (Munn, 2017). As a result, the threat caused by the presence of racial minorities should be the highest where the percentage of whites and non-whites is roughly the same.

At the heart of the matter, threat perception requires the coexistence of these stratifications. While previous findings have often faltered on the question of race, one potential reason is that racial threat in fact defies linear expectations. Examinations of non-government racial violence indicate that such incidents occur as racial groups converge in number; meaning that in order for a threat to be perceived, two distinct classes must coexist (Blalock, 1967). Within this framework, racial minorities include non-whites as a whole rather than just blacks. A large body of literature defines racial threat as the non-white population's size relative to that of the white population (O'Connell, 2012).

Theories of racial threat typically focus on non-government actors. At the local level, however, government and non-government actors have heavy overlap. If the logic of racial threat holds, civilian-police interactions will become tenser as the size of white and non-white communities approach each other. In other words:

\section{H2: The non-white population of a county will have a parabolic relationship with FIPs.}


Such understandings of racial threat should also re-inform expectations regarding inequality. "Affluence threat" describes a phenomenon in which the size and strength of the lower economic strata provides a sense of threat to the upper economic strata. In short, where rich and poor coexist in equal numbers, and where economic strata have the most mobility.

Previous studies treat inequality, measured by GINI coefficients, as a linear causal mechanism. There exists a negative correlation between GINI coefficients and communal health; higher income inequality is linked not only to FIPs, but also lack of social mobility (Andrews, 2008), suicide rates (Machado et al, 2015), and the ratio of male-to-female suicides (Noh, 2009). Still, such readings may not paint the whole picture; as with findings on race, they do not account for quadratic effects, which in turn incorporate the component of threat. GINI coefficients have the potential for quadratic effects because they can imply a lack of mobility at both high and low values.

According to Yu and Wang (2017), GINI scores can have both signal effects and jealousy effects, meaning that up to an inflection point they can indicate communal health rather than weakness. In the context of FIPs, however, I argue that the greatest effect should occur at the highest levels of social mobility, meaning the middle values of GINI coefficients; at higher and lower levels, a lack of threat perception will have a depressant effect. The threat perception should be highest when there exists the greatest possibility for class mobility, because these are the settings in which the question is not "settled," soto-speak. Essentially:

\section{H3: The GINI coefficient of a county will have a parabolic relationship with FIPs.}

Some studies suggest departments rather than counties should be observed to examine deviations in department policy (Lawson, 2018); others suggest that counties should be observed due to environmental factors (Delehanty et al, 2017; Gray \& Parker, 2020). The above theorizing suggests that regardless of what level of police respond to a situation, they will adapt more aggressive stances in places with higher threat perceptions. This question is less one of police practices in and of themselves than it is of historical and cultural legacies that inform such actions; as such, it suggests difficulty in combatting police killings from the top-down rather than the bottom-up.

The question of "bad apples" assumes that if individual officers act fairly and without regard to prejudices, discrepancies between races and classes will cease. If, however, historical and cultural legacies exist that disproportionately sort people into specific outcomes, efforts to combat poor treatment of underprivileged groups must address the condition of those groups, and the conditioning of those responding to them, rather than simply weeding out the poor crops. Bad seeds will yield bad apples regardless.

\section{$\underline{\text { Research Design }}$}

[Table 1 about here] 
I use a negative binomial as well as logit model to gauge the impact of the variables of interest on FIPs. Here, the dependent variable is collected at the county-level. This data is collected from 2013-2019 by the Mapping Police Violence dataset. The dataset is organized by ZIP code. It was merged with a dataset of FIPS codes which was then merged into the datasets for other variables of interest. For the purpose of these tests it is divided both by county-year as well as county totals for the observed period.

The number of FIPs varies significantly from 0 to 61 for given years and 0 to 237 for county totals. The nature of the data suggests the use of count models such as negative binomial or Poisson regressions. At the same time, a disproportionate number of counties have experienced zero both within given years as well as total. As such, the question is both one of binary likelihood as well as overall number; this would suggest the use of zeroinflated count models. Still, scholars have demonstrated that negative binomial count models can account for dispersion in ways that Poisson models cannot, and that zeroinflated models often do not improve upon negative binomial models (Allison 2012, p. 283). As such, rather than use a two-stage zero-inflated model, this study will employ logit and negative binomial models.

The primary independent variables of interest are property value, income inequality, and non-white population percent. Property values are defined as the median value of owner-occupied housing, organized by FIPS code; inequality as GINI coefficients for income for a given FIPS code; non-white populations as defined by 100 - the percent identifying race as white alone. For property values, skewness in certain areas such as New York is accounted for using log-values. Property values are not weighted by state, census division or census region; I discuss an alternative method for adjustment below.

Each of the above variables appears in the American Community Survey, using fiveyear estimates for the period of 2012-2018. As such, the FIPs data is lagged by one year. The American Community survey relies on five-year estimates due to gaps in data collection. Significant skewness exists in the affluence threat value as defined, thus requiring the use of a logarithmic value. Because the hypothesized relationships between inequality and FIPs, as well as race and FIPs, entails parity between white and non-white population sizes, a quadratic expression is included.

To gauge the impact that the historical legacy of racial sorting plays, as well as the degree to which wealth disparities are perceived as affluence threats, I will follow the initial models with a series of interactions, demonstrating the marginal effects of each of these variables. These models add to previous studies such as Helms \& Constanza (2019) and Gray \& Parker (2020) first by incorporating property values as a causal mechanism, second by demonstrating the "threat" element of inequality and race - as previously proposed by Jacobs \& O'Brien (1998) - and third by illustrating the manner in which these terms interact.

For robustness I have also employed a separate measure of property values using the median home price by county as provided by the National Association of Realtors. This 
measure adjusts the ACS property values for changes in the Housing Price Index. This data is specifically for 2019. As such, when employing this value, I use cross-sectional data relying on county totals of FIPs for the observed period. Here, the other variables of interest are held fixed at the 2010 US census values. While this leads to temporal discrepancies, the nature of the analysis suggests that intercounty differences should outweigh intracounty ones, meaning that changes within one county over time will be less important than differences between counties at a given point in time. This is a separate vantage point by which to view the subject material and as such is included simply as an alternative series of models.

For controls, I have first included population, measured in thousands, a dummy variable to account for the southern legacy of violence (cf. Kwon \& Cabrera, 2017), and a measure of rurality using the rural urban continuum. I use rurality rather than regions on the grounds that sociopolitical divisions between rural and urban have proven pervasive and consistent throughout the country (cf. Kramer, 2016; Scala \& Johnson, 2017).

In addition, I employ a series of variables derived from Senator Mike Lee's Social Capital Index (2018). These controls have previously been employed to demonstrate the impact of such measures on public displays of violence such as mass shootings (Szendro, ND). These measures include, the poverty rate, the number of high school graduates per capita, the unemployment rate, the population density, and the violent crime rate. Social capital is important because it speaks to community cohesion and trust. A lack of cohesion and trust between citizens and law enforcement should have a demonstrable effect on policing outcomes. I have used log values if the skewness is above .5.

At the same time, the social capital index does not vary by time. While some of these variables can indeed be collected temporally through the American Community Survey, others cannot. Most critically is the measure of religious congregations per capita, a measure that has a strong effect on social capital, and the mass shootings data, but is difficult to compile in more comprehensive fashion (Szendro, ND). For the sake of consistency, these controls are set at the Social Capital Index values. For robustness I will include these controls both with the time variant data as well as the cross-sectional data but will also include the time variant data without.

Lastly, I entered two additional variables designed to measure "social capital," as demonstrated by Kwon \& Cabrera (2019). These include the suicide rate, using data from the Center for Disease Control, as well as the percent of the population renting rather than owning homes, as provided by the US census. In the interest of consistency amongst the control variables, the suicide rate was taken for 2010. It averages the number of suicides for a county experienced for the years 2004-2010. The CDC does not report annual suicide statistics in counties where the number is below 20 due to confidentiality concerns. As such, counties that averaged below this threshold were not listed for that year. Population density, suicide rate, and violent crime are all log-values to account for skewness.

$\underline{\text { Results }}$ 
[Table 2 about here]

[Fig. 1-3 about here]

Table 2 shows output from negative binomial and logit models. Results indicate that property values are indeed associated with greater killings by police as well as the likelihood of any killing by police taking place within the observed period. This effect is significant at the .01 level in each model. In other words, when tasked with protecting property, police become increasingly violent.

Log-value coefficients indicate unit changes relative to percent increases rather than absolute. This means that the coefficient describes the result of a one-percent increase in the independent variable. An easier way to contextualize this is through the use of Incidence Rate Ratios (IRRs), which calculate the percent change in the dependent variable (Piza, 2012). In a model including these IRRs, the log-value of property values yields an IRR of 1.271. This means that for every one percent increase in property values, there is a roughly 27 percent increase in FIPs. The suicide rate yields an even higher IRR, with a one percent increase in suicides equated with a 147 percent increase in FIPs. This model is available in the appendix.

Adding quadratic expressions to GINI coefficients and non-white population numbers indicate that these effects decline as the numbers increase. The square term for the quadratic expressions are negative and significant at the .01 level, lending credence to the threat perception argument.

To gauge the turning point in the effect of the GINI coefficient and non-white population percent, it is necessary to calculate the vertex of the quadratic function. The vertex of the quadratic function is equal to the linear coefficient term divided by two times the absolute value of the quadratic coefficient term. As such, the vertices for the GINI coefficient are:

- Negative binomial: .678/(2*0.00749) $=45.2603471295$

- Logit: .624/(2*0.00719) $=43.3936022253$

Whereas the vertices for the non-white population are:

- Negative binomial: .0170/(2*.000200) $=42.5$

- Logit: .00372/(2*0.0000657) $=28.3105023$

This being said, it is important to note that the non-white population is associated with an increase in the overall number of killings by police, but not the likelihood of one occurring to begin with; I will discuss this phenomenon in the interactive effects below. As a result, the vertex of the non-white population does not have any statistical significance, hence its incongruity.

In effect, the models point to an inflection point in observations where the nonwhite population converges on the white population in percentage, and also where wealthy 
and poor populations converge in size. Both affluence threat and racial threat feature effects that outweigh economic measures in terms of their impact, with the poverty rate not even appearing significant.

Such findings underscore the importance of communal trust in the role of peacekeeping operations by police. It stands to reason that if the poor or non-white population starts to outnumber the wealthy or white population, police themselves are more likely to come from these communities; thus the threat perceived by the wealthy or white populations does not exert the same effect. Alternatively, such results may also indicate that police simply avoid neighborhoods overpopulated with such groups.

As for the fixed effects, the rural-urban continuum indicates that all levels relative to the highest metropolitan rating are associated with fewer killings by police; this indicates that FIPs are far more likely in metropolitan settings, which is attested to by the strong effect of population density. It also follows intuitively given relative population sizes. Lastly, it speaks to the racial divide, as poor blacks tend to concentrate in urban areas much more than poor whites.

For robustness, I repeated these tests using House Price Index adjustments for property values as provided by the National Association of Realtors. This measure is somewhat more problematic because it does not exist at the county-level for each of the observed years. As such, I have deployed the 2019 measures and set the year value to 2018 . Using prices rather than value speaks more to barriers for entry rather than preaccumulated wealth. In this case, the independent variables of interest feature a one-year lag, while the control variables are fixed at a nine-year lag. Shortcomings aside, this test provides another angle of evidence. The results hold constant.

Having established that property, inequality and race each exert an impact on FIPs, it becomes imperative to sort out the interactions between the three dynamics.

\section{$\underline{\text { Calculating marginal effects }}$}

Thus far, I have argued that capital, rather than inequality, "sets the stakes" meaning that race and inequality exert their influence over the range of property values. Still, each of these factors overlap through their historical constructions. Due to the longstanding traditions of racial sorting, non-whites in the United States disproportionately occupy the category of "threat" even along class lines. Poor whites feared the presence of non-whites due to the threat that they would lose their parity with wealthy whites as nonwhites made social, economic and political advances. Even as recently as the construction of Levittown in the post-World War II era, which long banned non-whites from residency due to the fear that property values might fall (Rothstein, 2017).

Where one lives is both a determinant and product of social status; social status encapsulates wealth but can more broadly speak to mobility or social capital. In the United States, property forms the backbone of social status. Within this norm exists two distinct hoops: whether one can own and accumulate capital at all, and what its value is if one does. 
Such elements have a direct impact on civic engagement and representation (Gilbert et al, 2002; Shapiro, 2004).

The question of race gets to the heart of the matter; the norm of property ownership as an equalizer in the United States has never historically extended to nonwhite communities. While obviously slavery prevented land ownership, so too did practices after the fact. The existence of "sundown towns" in the north persisted throughout the Jim Crow era, using either explicit laws or implicit force to deny black residency (O'Connell, 2009). Segregation enabled white legislators to sequester black populations in densely populated neighborhoods without available land (Rothsten, 2017).

Even following desegregation, the practice of redlining continued such efforts offthe-books. Black people seeking property ownership found themselves facing disadvantageous mortgaging practices that rendered such ownership more difficult than their white peers, and often times even impossible. This had the effect of limiting inherited wealth for blacks compared to their white counterparts (Shapiro, 2004). Policies such as the war on drugs have led to an excess of non-violent arrests in black communities that dampen civic engagement and voting - important parts of social capital (Kenworthy, 1997). As a result, black net worth remains the lowest of all racial groups in America, with the median at roughly one-tenth that of whites (Tax Policy Center, 2019). This renders black families far less likely to own or accumulate property.

The historic position of blacks as a permanent underclass in American society has cast the black population as an inherent threat in the broader culture. Persistent stereotypes of "angry blacks" or criminal "thugs" perpetuating "riots" have their roots in historic, cultural threat perceptions on the part of wealthy whites. Such images have their roots in fears of black advancement following the end of slavery (Smiley \& Fakunle, 2017). Such fears became entrenched over the course of the post-reconstruction era, encapsulated in the 1915 film Birth of a Nation, which glorified the Ku Klux Klan as overthrowing tyrannical "negro domination" (Wallace, 2003).

Continued racial disparities may come as a surprise to many white Americans given that explicit racism has steadily declined for decades. On an individual basis, racist attitudes have become increasingly unpopular and subject to public derision and punishment. At the same time, socialization plays a major role in the construction of inequalities due to institutional and cultural memories that can be passed down even after systemic shifts take place (Corzine et al, 1983; O'Connell, 2019;). Slavery, segregation and vigilantism in both the north and south have contributed to racial inequalities in wealth and wealth accumulation (Shapiro, 2004; 0'Connell 2012).

Such norms have indeed extended beyond the black community and towards other racial minorities as well. Barriers to property ownership have most consistently fallen on the black community due to its uninterrupted presence, whereas most other racial minorities have hailed from immigrant groups that came in waves (Pedraza, 1994). Other consistently present racial minorities, however, include both Native Americans and Hispanics. 
Barriers to capital accumulation have existed in many forms, and these lead to concentration of populations in neighborhoods that have an aggregate lack of social and physical capital. Hispanic families' median net worth is still less than one-eighth that of whites. Hispanic communities may face frequent raids for suspected illegal immigrants, which has a depressant effect on social capital (Hacker et al, 2011; Hagan et al, 2015). Questions regarding a person's ancestry may make it difficult to obtain employment, which can reduce the overall health of a community (Valdez et al, 2013).

There exists in the United States a phenomenon by which racial minorities can achieve social mobility through assimilation — in effect, by becoming white. This holds especially true for immigrants, and definitions of whiteness have changed over time to reflect the introduction of groups perceived as more or less white (Foley, 1998; Rosen 2009, p. 62; Gibson, 2019). Following the "broken windows" logic, institutional suspicion cast toward Hispanic communities prevents assimilation in a similar vein to that of black communities.

The question of assimilation has also faced indigenous tribes, and these questions have indeed hampered the ability to accumulate capital. While tribes maintain sovereignty from states, they cannot claim such rights in relation to the federal government - tribal land is held in trust by the department of interior. Property ownership norms differ between many traditional indigenous practices and American concepts; the tension between the two has historically situated tribal land as government property, a phenomenon that is only gradually overturning (McCulley, 2005).

White poverty exists; but poor blacks tend to live in concentrated urban areas, while poor whites are dispersed (Amato \& Zuo, 1992). Rural areas feature lower property costs, lower crime, less police presence and greater communal identity norms such as religious affiliation that alleviate communal stresses. All else being equal, a police force that protects property over people will target impoverished black and white communities alike, but black communities will bear the brunt both due to disproportionate numbers and differences in communal norms.

This picture has not become less complicated with time, as racial disparities have continued to exist, while class disparities have only started to grow (cf. Piketty, 2013)." In other words, there are multiple layers of "stakes." Property, here, acts as the primum movens in which a threat atmosphere occurs; the next is race, then class. In other words, race and inequality are dynamics that unfold across the range of property values. High property values suggest higher "stakes"; low property values suggest low "stakes". As such, they should amplify or reduce effects of race or class disparities accordingly. We should see the highest occurrence of fatal interactions with police in places with racial diversity, high social mobility, and high property values, but not with racial homogeneity, social mobility, or low property values.

In other words, we can amend the above hypotheses with the following: 


\section{H4: As property values increase, the GINI coefficient will exert a greater influence at middle levels as the non-white population approaches the white population in size. \\ H5: As property values increase, the GINI coefficient will exert a greater influence at higher and lower values in racially homogenous environments.}

In this scenario, it conceptually follows that these three variables should be interacted at once; due to the quadratic expressions in both GINI coefficients and housing prices, however, this is not feasible, as it requires two additional interaction terms, leading to a total of five, which results in covariation.

There are, however, alternative work-around measures. One alternative is to use a Herfindahl-Hirschman Index (HHI) to calculate a non-quadratic value for racial fractionalization. Fractionalization is a commonly used metric in comparative and international studies; it measures the diversity or lack thereof of the observed area. Lower values of fractionalization indicate greater diversity, whereas higher values indicate homogeneity. This is achieved by using the sum of square market shares. In this case, a simple HHI for race is calculated using $\left(x^{\wedge} 2+(100-x)^{\wedge} 2\right) / 100$, where $x=$ the non-white population percent of a county. The end result is an index ranging from 50 - indicating an equal number of whites and non-whites - to 100 - either indicating total white homogeneity or a complete lack of white population. A more complex variation of this measure, while not necessary for this particular analytic angle, would be calculated using square terms for each race's percent in a given county.

Using the HHI measure cuts down on one of the required interaction components. This lowers the total interaction terms to four which, while unconventional, is still feasible.

[Table 4 about here]

Table 4 shows results of the marginal effects, as illustrated in fig. 4-5. The negative binomial test was repeated including all constitutive terms. Significance levels in such tests are not indicative of the significance of marginal effects at varying levels due to increased collinearity (Brambor et al, 2006). Nevertheless, each constitutive term was significant in these tests. Still, interpreting conditional marginal outputs allows for a more in-depth analysis. In this case, the control variables are held at their mean and the marginal effect is produced across varying levels of the interaction terms.

\section{[Table 5 about here]}

[Fig. 4-6 about here]

Table 5 shows the results, as illustrated in fig. 6. We indeed see racially mixed areas peaking at mid-level inequality values, and racially homogenous areas at higher and lower. Racially homogenous areas in fact show a higher peak at lower levels of inequality, rather than higher, but retain wide confidence intervals on either end; part of the reason for this is 
a dearth of observations as the upper levels of GINI coefficients, making them somewhat harder to predict. The upper band of confidence intervals at high ends of GINI coefficients in fact reaches roughly the same position of that as the lower end.

By contrast, while the racially homogenous areas show a wider range of possible values, racially mixed areas show a more consistent trend. The range of possible outcomes is much smaller, with a clear and decisive peak at the middle-level of inequality. This peak is less pronounced than the low-end GINI peak for racially homogenous areas, but with smaller confidence intervals.

In other words, the pattern that emerges indicates that racial competition has a consistent effect; socioeconomic mobility increases fatal police encounters in racially mixed areas. By contrast, immobility leads to sporadic outbursts of fatal police encounters in racially homogenous areas, but these events appear somewhat less predictable. Such findings explain the lack of significance for racial composition in binary models, as opposed to its significance in count models - police killings do have peaks in racially homogenous areas, but these are less predictable and therefore not necessarily as pronounced.

When comparing the effect of property over race divided by inequality, we see that the effect at middle-levels of inequality clearly declines as areas become more racially homogenous. At the lower levels, with the highest peak, the effect increases at higher levels but in a less-established pattern, with a wider range of possible outcomes both higher and lower than the comparable category.

Such results speak to the far-reaching historical effect that racially competition has played on its economic counterparts. In effect, the presence of a racial threat eliminates the presence of an affluence threat; in early American history, competition with non-whites placated the grievances of poor-whites. These historical remnants now indicate a ripple effect in institutions that, on paper, are far removed from these events.

Essentially, in the absence of racial threat, a lack of social mobility becomes the primary cause of tension. Across the board, these loci occur where property values are higher. Such findings once again bolster support for the notion that property values "set the stakes," followed by race. Indeed, class tensions have an entirely different dynamic in racially homogenous settings compared to diverse ones. In diverse settings, social mobility is a driver; in homogenous ones, it is a depressant. In other words, the question of class in America almost entirely hinges on the question of race, and both revolve around the enduring legacy of property ownership norms.

It is a bit of a leap to infer intent based on these environmental characteristics. If one assumes that the role of police is to maintain "order," and that the concept of order relates to both competition and violence, these dynamics may be seen as indicators of demographic conflict. In other words, areas within one racial group fracture along class lines, but in the presence of racial divisions violence discriminates on race instead. The extent to which FIPs reflect the desires and tensions of the public is debatable and not 
necessarily illustrated in these findings. At the same time, such possibilities provide potential explanations and indicate pathways for further avenues of study.

The trend that the presence of race essentially flips the effects of economic competition, and suppresses effects in highly stratified areas, does support theoretical and historical allegations that wealthy whites have long used racial divisions to pacify poor whites. Indeed, these findings do indicate that civilian interactions with police follow along the lines of historical and theoretical cleavages.

If police are tasked with maintaining order, inequalities and competition matter. If nothing else, "order" entails safeguarding existing institutions; if these institutions uphold existing cleavages, police must necessarily reinforce them. In effect, regardless of motivations, police must operate within their institutional environment. These findings have not passed judgment on such motivations, but they have indeed indicated that killings by police officers follow along institutional patterns. Existing environments of competition and threat perceptions between races and classes creates a fatal witch's brew in-and-ofitself that can reinforce disparities regardless of intentions.

The clear pattern emerging from these tests told a story - one where property matters more than people, and certain types of people are seen as threats.

\section{Discussion}

In the film BlacKKKlansman, the Colorado Springs police department expunges racism from its midst when the police chief collaborates with a black detective to arrest a wayward cop for police brutality. Although the film ends with a reminder that racism endures, it paints the issue as a matter of individual perceptions. In the context of the film, the police department is initially reluctant to confront the racist officer because they protect their own, and don't have any black employees; after their new, black detective carries out a successful mission against the Klan, the department comes to its senses and simply removes the one racist that drags them down.

Findings such as these paint a much more complex picture. Issues concerning race, class, and their intersection create highly volatile contexts in which institutions operate. Police use excessive force to maintain order; order is pre-defined in an exclusive way. In other words, it need not be true that police are racist in order to perpetuate racism. A police force without a single racist officer can still discriminate by virtue of macro-level inequalities.

It's hard to establish intent; it's much easier to establish norms. The norm of property ownership and competition in America creates an atmosphere in which police will protect property over people. That does not speak to any particular department's mission statement - only to the environment in which it operates. On a normative level, it poses difficulties even for police who genuinely want to serve the public good. 
The fixation in American history on property ownership as a way of life lies on the crux of issues concern violence along racial and class lines. If these norms are deeply entrenched, protecting property and property owners will remain a fixation of law enforcement, and detract from missions to serve public welfare. Connections between property ownership and violence remain relevant not just because of their history but because violence lingers as a common American solution to property violations.

During the recent George Floyd protests, several incidents indicated a tendency for bystanders to use lethal force against looters or even non-violent protesters. Perhaps the most high-profile incident is that of Kenosha, Wisconsin, in which the shooting of protesters by a gunman attracted debate regarding protesters' descrution of property; others include Omaha, Nebraska, where a bar-owner shot and killed a looter, for which no charges were brought (Bandur, 2020), or a viral photo from St. Louis famously depicting a wealthy, mansion-owning couple brandishing firearms at peaceful demonstrators perhaps an encapsulation of affluence threat. When police raided the couple's home for illegal firearms, the President of the United States threatened to intervene (Rambaran, 2020). Most critically, the President of the United States encouraged the shooting of looters following the casing of a Target department store (Sprunt, 2020).

Any potential antidote to these problems will be long-term and complex. Clearly, however, it is not enough to simply address racist attitudes. First, the prioritization of property over people lends itself to the militarization of police, and the capacity for police violence. Second, the disparity in opportunity between races means that such violence will fall disproportionately on minority communities.

Racial minorities in The United States must have access to both social and physical capital in order to ameliorate their immediate situation. In particular, incarceration rates negatively impact social capital, which in turn breeds conditions that increase incarceration rates. Social isolation plays a major role in creating violent crime (Lea \& Young, 1984). Heavy-handed laws regarding black market commodities exacerbate the situation (Alexander, 2010). In addition, felons cannot vote and have difficulty obtaining employment and housing. As such, high incarceration rates deplete the overall health of communities. Communal trust also plays a major role in communal well-being. Non-local police officers do not have the same communal trust and therefore may have antagonistic relationships with local people (Lyons, 2002; Purdue, 2001). Once again, the United States stands out from its economic peers - issues with communal trust and policing most commonly appear in developing, post-authoritarian countries (Goldsmith, 2005).

Previous findings have demonstrated links between income inequality and killings by police. A wide variety of studies have struggled to find definitive links between race and police, with some affirming a connection and others failing to establish one. Others but have found that parity in racial population sizes, rather than the absolute population size of racial minorities, heavily correlate with racial violence. I extend this logic in the following ways: first, that property values correlate with killings by police; second, that both income inequality and racial composition have parabolic relationships with killings by police, meaning that they have their greatest effect at middle levels rather than higher levels; 
finally, that property values exacerbate the effects of income inequality and race, meaning that when property values are low, GINI coefficients and non-white populations correlate less with killings by police.

Each of these phenomena describe the threat perceptions of elites that play into policing tactics. In short, where property values are higher, police kill more people. Where poor and non-white people coexist with wealthy or white people, police kill more people. The higher property values are, the more race and class matter.

Another aspect that sticks out is the unexpectedly high connection between suicide rates and FIPs. Given that this fell outside the purview of the theoretical foundation, I did not discuss this phenomenon a length; at the same time, the fact that it does exhibit such a strong connection indicates that it is an area worth pursuing. Suicide rates demonstrate the largest effect of any of the controls, more than three times that of the violent crime rate. Such findings may speak to the degree to which communal cohesion breeds cycles of violence. Suicide rates are considered an indicator that a given community lacks social capital (Kwon \& Cabrera, 2019).

Future studies should further examine connections between suicide, communal health, and policing. This should be accomplished using more time-variant and up-to-date metrics than those used here. It does bolster the larger portrait of communal health in relation to policing. Apologists have often used the crime rate as justification for heavyhanded methods used by police; the fact that suicide rates exert a much stronger impact than violent crime indicates that there is something much more personal and psychological at play. The questions of social cohesion and mental health did not figure into the theoretical framework advanced above and as such went largely unanswered, but findings indicate that there is, in fact, another story to tell.

Results further underscore the importance of establishing community trust between law enforcement and their constituents. The fact that a high concentration of wealth actually seems to have a deleterious effect speaks to the notion that conflict between a small group and a much larger group is less likely than conflict between groups of relatively equal size. Having a disadvantaged group outnumber their advantaged peers makes it more likely that law enforcement comes from disadvantaged communities to begin with.

Further studies are needed to examine these phenomena. Perhaps most critically, future studies can examine cases of U.S. counties that have successfully curbed the occurrence of Fatal Interactions with Police to learn how to apply such techniques in new cases. Policymakers should invest in studies that propose policy-based solutions for issues surrounding communal health, social capital, and inequality. Community-oriented solutions that defer to local decision-makers may have a more positive impact than top-down, onesize-fits-all solutions. As it stands, recent developments have confronted the American psyche with a harsh truth: The United States remains a stand-out amongst its peers - for all the wrong reasons. 


\section{$\underline{\text { Works Cited }}$}

Alexander, Michelle. 2012. The New Jim Crow: Mass Incarceration In The Age of Colorblindness. New York, NY: The New Press.

Allison, Paul D. 2012. Logistic Regression Using SAS: Theory and Application, Second Edition. Cary, NC: SAS Institute.

Amato, Paul R. and Jiping Zuo. 1992. "Rural Poverty, Urban Poverty, and Psychological Well-Being." The Sociological Quarterly, 33(2): pp. 229-240.

Andrews, Dan and Andrew Leigh. 2008. "More Ienquality, Less Social Mobility." Discussion Paper No. 566.

Ayers, Edward L. 1984. Vengeance and Justice: Crime and Punishment in the 19th Century American South. New York, NY: Oxford University Press.

Bandur, Michelle. 2020. “Douglas County Attorney calls death 'senseless, but justified', no charges in shooting of protester." KETV Omaha. Published June 5, 2020.

$<$ https://www.ketv.com/article/officials-announce-no-charges-to-be-filed-at-this-time-inthe-death-of-22-year-old-james-scurlock/32733160>.

Belew, Kathleen. 2014. "Lynching and Power in the United States: Southern, Western, and National Vigilante Violence." History Compass, 12(1): pp. 84-99.

Berman, Eli and David D. Laitin. 2008. "Religion, terrorism and public goods: Testing the club model." Journal of Public Economics, 92(10-11): pp. 1942-1967.

Billington, Ray Allen and Martin Ridge. Westward Expansion: A History of the American Frontier. Albuquerque, NM: University of New Mexico Press.

Blalock, Hubert M. 1957. "Per cent non-white and discrimination in the South." American Sociological Review, 22: pp. 677-682.

Blalock, Hubert M. 1967. Toward a Theory of Minority-group Relations. Hoboken, NJ: Wiley.

Brambor, Thomas, William Roberts Clark, and Matt Golder. 2006. Political Analysis, 14: pp. 63-82.

Brown, Richard Maxwell. 1975. Strain of Violence: Historical Studies of American Violence and Vigilantism. New York, NY: Oxford University Press.

Center for Disease Control. 2010. "Violence Prevention: Suicide Resources." Available at: <http://www.cdc.gov/violenceprevention/suicide/statistics/>. 
Cesario, Joseph, David J. Johnson and William Terrill. 2018. "Is There Evidence of Racial Disparity in Police Use of Deadly Force? Analyses of Officer-Involved Fatal Shootings in 2015-2016." Social Psychology and Personality Science.

Cohen, Philip N. 1998. "Black Concentration Effects on Black-White and Gender Inequality: Multilevel Analysis for U.S. Metropolitan Areas.” Social Forces, 77(1): pp. 207-229.

Corzine, Jay, James Creech and Lin Corzine. 1983. "Black Concentration and Lynchings in the South: Testing Blalock's Power- Threat Hypothesis.” Social Forces, 61(3): pp. 774-796.

Davis, Diane E. 2010. "Irregular armed forces, shifting patterns of commitment, and fragmented sovereignty in the developing world." Theory and Society, 39: pp. 397-413.

De Tocqueville, Alexis. 1838. Democracy in America. Trans. Henry Reeve. Charlottesville, VA: University of Virginia.

Delehanty, Casey, Jack Mewhirter, Ryan Welch, and Jason Wilks. 2017. "Militarization and police violence: The case of the 1033 program." Research and Politics, April-June 2017: pp. 1-7.

Foley, Neil. 1998. The White Scourge: Mexicans, Blacks, and Poor Whites in Texas Cotton Culture. Berkeley, CA: University of California Press.

Gazit, Nir. 2014. "State-sponsored Vigilantism: Jewish Settlers' Violence in the Occupied Palestinian Territories.” Sociology, 49(3): pp. 438-545.

Gibson, Carrie. 2019. El Norte: The Epic and Forgotten Story of Hispanic North America. New York, NY: Grove Atlantic.

Goldsmith, Andrew. 2005. "Police reform and the problem of trust." Theoretical Criminology, 9(4): pp. 443-570.

Gone With The Wind. 1939. Directed by Victor Fleming.

Gray, Andrew C. and Karen F. Parker. 2020. "Race and police killings: between racial threat and police shootings of Black Americans." Journal of Ethnicity in Criminal Justice.

Hacker, Karen, Jocelyn Chu, Carolyn Leung, Robert Marra, Alex Pirie, Mohamed Brahimi, Margaret English, Joshua Bechmann, Dolores Acevedo-Garcia, and Robert P. Marlin. 2011. "The impact of Immigration and Customs Enforcement on immigrant health: Perceptions of immigrants in Everett, Massachusetts, USA." Social Science \& Medicine, 73(4): pp. 586-594.

Hagan, Jacqueline, David Leal and Nestor Rodriguez. 2015. “Deporting social capital: Implications for immigrant communities in the United States." Migration Studies, 3(3): pp. 370-392. 
Hagedorn, John M. 2005. “The Global Impact of Gangs.” Journal of Contemporary Criminal Justice, 21(2): pp. 153-169.

Harring, Sidney L. Policing a Class Society: The Experience of American Cities, 1865-1915. Chicago, IL: Haymarket Books.

Headle, Lura E. 1922. "Grants of land by the United States to our soldiers of past wars." Advocate of Peace through Justice, 84(5): pp. 176-178.

Helms, Ronald and S. E. Costanza. 2019. "Contextualizing race: a conceptual and empirical study of fatal interactions with police across US counties." Journal of Ethnicity in Criminal Justice.

Jacobs, David and Robert M. O’Brien. 1998. “The Determinants of Deadly Force: A Structural Analysis of Police Violence." American Journal of Sociology, 103(4): pp. 837-862.

Jefferson, Thomas. 1785. Notes on the State of Virginia. Cambridge, MA: Harvard University, 1853.

Jefferson, Thomas. 1800. "Letter from Thomas Jefferson to James Monroe." Library of Virginia. Available at

$<$ https://www.encyclopediavirginia.org/Letter_from_Thomas_Jefferson_to_James_Monroe_ September_20_1800>

Johnson, David J., Trevor Tress, Nicole Burkel, Carley Taylor, and Joseph Cesario. 2019. "Officer characteristics and racial disparities in fatal officer-involved shootings." Proceedings of the National Academy of Sciences, 116(32): pp. 15877-15882.

Kwon, Roy and Joseph F. Cabrera. 2019. "Social integration and mass shootings in U.S. counties." Journal of Crime and Justice, 42(2): pp. 121-139.

Lawson Jr., Edward. 2018. "Police Militarization and the Use of Lethal Force." Political Rsearch Quarterly.

Lea, John and Jock Young. 1984. What Is To Be Done About Law and Order? Harmondsworth, UK: Penguin Books.

Lowery, Wesley. 2016. They Can't Kill Us All: Ferguson, Baltimore, and a New Era in America's Racial Justice Movement. Boston, MA: Little, Brown and Company.

Lyons, William. 2002. "Partnerships, information and public safety: Community policing in a time of terror." Policing: An International Journal, 25(3): 530-542.

Machado, Borges, Rasella, Davide and Darci Neves dos Santos. 2015. "Impact of income inequality and other social determinants on suicide rates in Brazil." PLOS. 
Mapping Police Violence. 2020. <https://mappingpoliceviolence.org/>.

McCulley, Krisina L. 2005. "The American Indian Probate Reform Act of 2004: The Death of Fractionation or Individual Native American Property Interests and Tribal Customs?" American Indian Law Review, 30(2): pp. 401-422.

Messner, Steven F., Robert D. Baller, and Matthew P. Zevenbergen. 2005. "The Legacy of Lynching and Southern Homicide." American Sociological Review, 70: pp. 633-655.

Mitchell, Margaret. 1936. Gone With The Wind. New York, NY: Avon Publishing, 1973.

Mitrani, Sam. 2012. The Rise of the Chicago Police Department: Class and Conflict, 18501894. Champaign, IL: University of Illinois Press.

Monroe, James. 1800. “To Thomas Jefferson from James Monroe.” September 9, 1800. National Archives. Available at <https://founders.archives.gov/?q=Author\%3A\%22Monroe\%2C\%20James\%22\&s=11113 $11111 \& \mathrm{r}=266>$

Monroe, James. 1800. “To Thomas Jefferson from James Monroe.” September 15, 1800. National Archives. Available at <https://founders.archives.gov/?q=Author\%3A\%22Monroe\%2C\%20James\%22\&s=11113 $11111 \& \mathrm{r}=267>$

Moore Jr., Barrington. 1966. Social Origins of Dictatorship and Democracy: Lord and Peasant in the Making of the Modern World. Boston: Beacon Press.

Munn, Christopher W. 2017. "The One Friend Rule: Race and Social Capital in an Interracial Network." Social Problems, 65(4): pp. 473-490.

National Association of Realtors. 2019. "County Median Home Prices and Monthly Mortgage Payment." <https://www.nar.realtor/research-and-statistics/housingstatistics/county-median-home-prices-and-monthly-mortgage-payment>.

Noh, Yong-Hwan. 2009. "Does Unemployment increase suicide rates? The OECD panel evidence." Journal of Economic Psychology, 30(4): pp. 575-582.

Oberly, James W. 1985. "Gray-Haired Lobbyists: War of 1812 Veterans and the Politics of Bounty Land Grants." Journal of the Early Republic, 5(1): pp. 35-58.

0'Connell, Heather A. 2018. "Historical Shadows: The Links between Sundown Towns and Contemporary Black-White Inequality." Sociology of Race and Ethnicity, 5(3), 311-325.

Pedraza, Silvia. 1994. "Introduction from the Special Issue Editor: The Sociology oflmmigration, Race, and Ethnicity in America." Social Problems, 41(1): pp. 1-8. 
Piketty, Thomas. 2013. Capital in the Twenty-First Century. Trans. Arther Goldhammer, 2014. Cambridge, MA: Harvard University Press.

Piza, Eric L. 2012. "Using Poisson and Negative Binomial Regression Models to Measure the Influence of Risk on Crime Incident Counts." Rutgers Center on Public Security.

<http://www.rutgerscps.org/uploads/2/7/3/7/27370595/countregressionmodels.pdf>

Purdue, Derrick. 2001. "Neighbourhood Governance: Leadership,Trust and Social Capital." Urban Studies, 38(12): pp. 2211-2224.

Rambaran, Vandana. 2020. “Trump may intervene in case of St. Louis couple wielding guns at protesters, Missouri governor said." Fox News. Published July 15, 2020.

$<$ https://www.foxnews.com/us/trump-st-louis-couple-wielding-guns-protesters-missourigovernor>.

Reichel, Philip L. 1988. "Southern Slave Patrols as a Transitional Police Type." American Journal of Police, 7(2): pp. 51-78.

Rosen, Hannah. 2009. Terror in the Heart of Freedom: Citizenship, Sexual Violence, and the Meaning of Race in the Postemancipation South. Chapel Hill, NC: University of North Carolina Press.

Rothstein, Richard. 2017. The Color of Law: A Forgotten History of How Our Government Segregated America. New York, NY: Liveright.

Ruef, Martin and Ben Fletcher. 2003. "Legacies of American Slavery: Status Attainment among Southern Blacks after Emancipation." Social Forces, 82(2): pp. 445-480.

Scala, Dante J. and Kenneth M. Johnson. 2017. "Political Polarization along the Rural-Urban Continuum? The Geography of the Presidential Vote, 2000-2016." The Annals of the American Academy of Political and Social Science, 672(1): pp. 162-184.

Sellin, J. Thorsten. 1976. Slavery and the Penal System. New York, NY: Elsevier.

Shapiro, Thomas M. 2004. The Hidden Cost of Being African American: How Wealth Perpetuates Inequality. New York, NY: Oxford University Press.

Sharples, Jason T. 2020. The World That Fear Made: Slave Revolts and Conspiracy Scares in Early America." Philadelphia, PA: University of Pennsylvania Press.

Smiley, Calvin John and David Fakunle. 2016. "From 'brute' to 'thug:' the demonization and criminalization of unarmed Black male victims in America." Journal of Human Behavior in the Social Environment, 26(3-4): pp. 350-366.

Social Capital Project, The. 2018. "The Geography of Social Capital in America." SCP Report No. 1-18. April 2018. 
Spitzer, Steven and Andrew T. Skull. 1977. "Privatization and Capitalist Development: The Case of the Private Police." Social Problems, 25(1): pp. 18-29.

Sprunt, Barbara. 2020. "The History Behind 'When The Looting Starts, The Shooting Starts."” NPR. Published May 29, 2020. <https://www.npr.org/2020/05/29/864818368/the-history-behind-when-the-lootingstarts-the-shooting-starts>.

Stuart, Paul. 1987. Nations Within a Nation: Historical Statistics of American Indians. Greenwood Press.

Szendro, Brendan. No Date. "Community, Faith, and Public Violence: Assessing the impact of religion on mass shootings in America." Working paper.

Tax Policy Center. 2019. "Median Value of Family Net Worth by Race or Ethnicity, 2016." Urban Institute \& Brookings Institution. <https://www.taxpolicycenter.org/fiscalfact/median-value-wealth-race-ff03112019>.

Tigges, Leann M. and Deborah M. Tootle. 1993. “Underemployment and Racial Competition in Local Labor Markets.” The Sociological Quarterly, 34(2): pp. 279-298.

Turner, Frederick Jackson. 1921. The Frontier in American History. New York, NY: Henry Holt.

U.S. Bureau of the Census. 2010. Census of the Population. Washington, D.C.: Government Printing Office.

U.S. Bureau of the Census. 2018. 2012-2018. American Community Survey 5-year Public Use Microdata Samples. Accessed using Social Explorer $<$ https://www.socialexplorer.com/>

Valdez, Carmen R., Brian Padilla and Jessa Lewis Valentine. 2013. "Consequences of Arizona's Immigration Policy on Social Capital Among Mexican Mothers With Unauthorized Immigration Status." Hispanic Journal of Behavioral Sciences, 35(3), pp. 303-322

Wallace, Michele Faith. 2003. "The Good Lynching and 'The Birth of a Nation': Discourses and Aesthetics of Jim Crow." Cinema Journal, 43(1): pp. 85-104.

Williamson, Jeffery G. 1987. "Is Inequality Inevitable Under Capitalism? The American Case" in Berger, Peter L. 1987. Modern Capitalism, Volume 1: Capitalism and Equality in America. University Press of America, pp. 48-84. 
Tables

\begin{tabular}{lccccc}
\hline VARIABLES & Observations & Mean & Std. deviation & Minimum & Maximum \\
\hline Total police killings & 22549 & .3922569 & 1.545443 & 0 & 62 \\
Median home value & 22532 & 135531.9 & 80784.49 & 18700 & 1056500 \\
GINI coefficient & 22541 & 44.30853 & 3.68776 & 25.67 & 6647 \\
Non-white percent & 22542 & 16.81862 & 16.84812 & 0 & 96.88989 \\
Median home price & 3085 & 159437.3 & 102464.2 & 35114 & 1195477 \\
Percent renting & 3103 & 24.11042 & 7.109139 & 5.800992 & 72.78172 \\
Poverty rate & 3103 & 16.41524 & 6.50111 & 1.8 & 48.7 \\
High school grads & 3103 & 85.78221 & 6.544634 & 48.5 & 98.7 \\
Population density & 3103 & 265.6892 & 1793.961 & .1 & 71615.8 \\
Suicide rate & 3103 & 224.5252 & 152.0217 & 4.504788 & 6578.947 \\
Violent crime rate & 3003 & 243.7162 & 189.0174 & 9 & 1717.7 \\
Voting rate & 3103 & 59.21399 & 9.595653 & 13.1 & 92.5 \\
Rural-urban & 3103 & 4.989687 & 2.702034 & 1 & 9 \\
continuum & 7 & & & & \\
Year & & & & & \\
\hline
\end{tabular}

Table 1: Descriptive statistics 


\begin{tabular}{|c|c|c|}
\hline VARIABLES & Total FIPs & $\begin{array}{l}\text { Probability } \\
\text { of any FIP }\end{array}$ \\
\hline Property values (log) & $\begin{array}{l}0.306 * * * \\
(0.0473)\end{array}$ & $\begin{array}{l}0.217 * * * \\
(0.0673)\end{array}$ \\
\hline GINI coefficient & $\begin{array}{c}0.678 * * * \\
(0.0831)\end{array}$ & $\begin{array}{l}0.624 * * * \\
(0.118)\end{array}$ \\
\hline $\begin{array}{l}\text { GINI coefficient } \\
\text { (squared) }\end{array}$ & $\begin{array}{c}-0.00749 * * * \\
(0.000912)\end{array}$ & $\begin{array}{c}-0.00719 * * * \\
(0.00131)\end{array}$ \\
\hline $\begin{array}{l}\text { Non-white population } \\
\text { percent }\end{array}$ & $\begin{array}{l}0.0170 * * * \\
(0.00320)\end{array}$ & $\begin{array}{c}0.00372 \\
(0.00438)\end{array}$ \\
\hline $\begin{array}{l}\text { Non-white population } \\
\text { percent (squared) }\end{array}$ & $\begin{array}{c}-0.000200 * * * \\
(4.46 \mathrm{e}-05)\end{array}$ & $\begin{array}{l}-6.57 \mathrm{e}-05 \\
(6.51 \mathrm{e}-05)\end{array}$ \\
\hline $\begin{array}{l}\text { Percent population } \\
\text { renting (log value) }\end{array}$ & $\begin{array}{l}0.263 * * * \\
(0.0767)\end{array}$ & $\begin{array}{c}0.275 * * * \\
(0.0953)\end{array}$ \\
\hline Poverty rate & $\begin{array}{l}0.0147 * * * \\
(0.00526)\end{array}$ & $\begin{array}{l}0.0274 * * * \\
(0.00654)\end{array}$ \\
\hline $\begin{array}{l}\text { Percent highschool } \\
\text { graduates }\end{array}$ & $\begin{array}{c}-0.0112 * * * \\
(0.00380)\end{array}$ & $\begin{array}{l}-0.00507 \\
(0.00512)\end{array}$ \\
\hline Population density (log) & $\begin{array}{c}0.209 * * * \\
(0.0158)\end{array}$ & $\begin{array}{l}0.122 * * * \\
(0.0233)\end{array}$ \\
\hline Unemployment rate (log) & $\begin{array}{c}0.0975 \\
(0.0623)\end{array}$ & $\begin{array}{c}0.211 * * * \\
(0.0814)\end{array}$ \\
\hline Suicide rate (log) & $\begin{array}{c}0.813 * * * \\
(0.0586)\end{array}$ & $\begin{array}{c}0.817 * * * \\
(0.0753)\end{array}$ \\
\hline Violent crime rate $(\log )$ & $\begin{array}{l}0.286 * * * \\
(0.0278)\end{array}$ & $\begin{array}{l}0.205 * * * \\
(0.0333)\end{array}$ \\
\hline Population (thousands) & $\begin{array}{c}0.00883 * * * \\
(0.000374)\end{array}$ & $\begin{array}{c}0.0418 * * * \\
(0.00196)\end{array}$ \\
\hline Rural-urban continuum & $\begin{array}{c}-0.217 * * * \\
(0.00990)\end{array}$ & $\begin{array}{c}-0.179 * * * \\
(0.0117)\end{array}$ \\
\hline
\end{tabular}




\begin{tabular}{|c|c|c|}
\hline South & $\begin{array}{l}-0.0385 \\
(0.0350)\end{array}$ & $\begin{array}{c}0.234 * * * \\
(0.0522)\end{array}$ \\
\hline \multicolumn{3}{|l|}{ Year } \\
\hline 2013 & $\begin{array}{l}0.00818 \\
(0.0547)\end{array}$ & $\begin{array}{c}0.0390 \\
(0.0766)\end{array}$ \\
\hline 2014 & $\begin{array}{l}0.117 * * \\
(0.0538)\end{array}$ & $\begin{array}{c}0.261 * * * \\
(0.0747)\end{array}$ \\
\hline 2015 & $\begin{array}{c}0.0781 \\
(0.0543)\end{array}$ & $\begin{array}{c}0.206 * * * \\
(0.0753)\end{array}$ \\
\hline 2016 & $\begin{array}{l}0.109 * * \\
(0.0541)\end{array}$ & $\begin{array}{c}0.258 * * * \\
(0.0751)\end{array}$ \\
\hline 2017 & $\begin{array}{c}0.177 * * * \\
(0.0535)\end{array}$ & $\begin{array}{c}0.301 * * * \\
(0.0748)\end{array}$ \\
\hline 2018 & $\begin{array}{c}0.157 * * * \\
(0.0538)\end{array}$ & $\begin{array}{c}0.267 * * * \\
(0.0752)\end{array}$ \\
\hline Dispersion parameter & $\begin{array}{c}-0.578 * * * \\
(0.0537)\end{array}$ & \\
\hline Constant & $\begin{array}{c}-26.79 * * * \\
(2.015)\end{array}$ & $\begin{array}{c}-24.69 * * * \\
(2.813)\end{array}$ \\
\hline Observations & 21,016 & 21,016 \\
\hline
\end{tabular}

Table 2: Results for property values 


\begin{tabular}{|c|c|c|}
\hline VARIABLES & Total FIPs & $\begin{array}{l}\text { Probability } \\
\text { of any FIP }\end{array}$ \\
\hline Home prices $(\log )$ & $\begin{array}{l}0.427 * * * \\
(0.119)\end{array}$ & $\begin{array}{l}0.464 * * * \\
(0.168)\end{array}$ \\
\hline GINI coefficient & $\begin{array}{l}0.587 * * * \\
(0.214)\end{array}$ & $\begin{array}{c}0.758 * * \\
(0.310)\end{array}$ \\
\hline GINI coefficient ${ }^{\wedge} 2$ & $\begin{array}{c}-0.00668 * * * \\
(0.00233)\end{array}$ & $\begin{array}{c}-0.00887 * * * \\
(0.00343)\end{array}$ \\
\hline $\begin{array}{l}\text { Non-white population } \\
\text { percent }\end{array}$ & $\begin{array}{l}0.0227 * * * \\
(0.00845)\end{array}$ & $\begin{array}{c}0.0133 \\
(0.0113)\end{array}$ \\
\hline $\begin{array}{l}\text { Non-white population } \\
\text { percent }^{\wedge} 2\end{array}$ & $\begin{array}{c}-0.000310^{* *} \\
(0.000122)\end{array}$ & $\begin{array}{l}-0.000164 \\
(0.000170)\end{array}$ \\
\hline $\begin{array}{l}\text { Percent population } \\
\text { renting (log) }\end{array}$ & $\begin{array}{c}0.156 \\
(0.200)\end{array}$ & $\begin{array}{l}0.0956 \\
(0.246)\end{array}$ \\
\hline Poverty rate & $\begin{array}{c}0.0401 * * * \\
(0.0132)\end{array}$ & $\begin{array}{c}0.0459 * * * \\
(0.0166)\end{array}$ \\
\hline $\begin{array}{l}\text { Percent highschool } \\
\text { graduates }\end{array}$ & $\begin{array}{c}-0.0154 \\
(0.00974)\end{array}$ & $\begin{array}{c}-0.0296 * * \\
(0.0128)\end{array}$ \\
\hline Population density (log) & $\begin{array}{l}0.245 * * * \\
(0.0418)\end{array}$ & $\begin{array}{l}0.202 * * * \\
(0.0598)\end{array}$ \\
\hline Unemployment rate (log) & $\begin{array}{l}0.0775 \\
(0.164)\end{array}$ & $\begin{array}{c}0.217 \\
(0.209)\end{array}$ \\
\hline Suicide rate (log) & $\begin{array}{l}0.680 * * * \\
(0.156)\end{array}$ & $\begin{array}{l}0.573 * * * \\
(0.194)\end{array}$ \\
\hline Violent crime rate $(\log )$ & $\begin{array}{l}0.214 * * * \\
(0.0713)\end{array}$ & $\begin{array}{c}0.120 \\
(0.0851)\end{array}$ \\
\hline Population (thousands) & $\begin{array}{c}0.00769 * * * \\
(0.00101)\end{array}$ & $\begin{array}{l}0.0289 * * * \\
(0.00454)\end{array}$ \\
\hline Rural-urban continuum & $\begin{array}{c}-0.188 * * * \\
(0.0257)\end{array}$ & $\begin{array}{c}-0.161 * * * \\
(0.0302)\end{array}$ \\
\hline
\end{tabular}


South

$-0.0652$

$-0.123$

(0.0920)

$(0.132)$

Dispersion parameter

$-0.457 * * *$

(0.134)

Constant

$-24.57 * * *$

$-26.13 * * *$

(5.208)

(7.370)

Observations

2,984

2,984

Standard errors in parentheses

$* * * \mathrm{p}<0.01, * * \mathrm{p}<0.05, * \mathrm{p}<0.1$

Table 3: Results for housing prices 


\begin{tabular}{|c|c|}
\hline $\begin{array}{l}\text { At: levels of } \\
\text { property values }\end{array}$ & $\begin{array}{l}\text { Interaction } \\
\text { effect }\end{array}$ \\
\hline 1bn._at & $\begin{array}{l}-0.0310 \\
(0.0462)\end{array}$ \\
\hline 2._at & $\begin{array}{l}-0.00338 \\
(0.0154)\end{array}$ \\
\hline 3._at & $\begin{array}{l}0.0112 \\
(0.00919)\end{array}$ \\
\hline 4._at & $\begin{array}{l}0.0178 * \\
(0.0107)\end{array}$ \\
\hline 5._at & $\begin{array}{l}0.0199 \\
(0.0137)\end{array}$ \\
\hline 6._at & $\begin{array}{l}0.0194 \\
(0.0171)\end{array}$ \\
\hline 7._at & $\begin{array}{l}-0.0351 \\
(0.0522)\end{array}$ \\
\hline 8._at & $\begin{array}{l}0.00420 \\
(0.0229)\end{array}$ \\
\hline 9._at & $\begin{array}{l}0.0285 * \\
(0.0160)\end{array}$ \\
\hline 10._at & $\begin{array}{l}0.0422 * * \\
(0.0178)\end{array}$ \\
\hline 11._at & $\begin{array}{l}0.0489 * * \\
(0.0216)\end{array}$ \\
\hline 12._at & $\begin{array}{l}0.0509 * \\
(0.0265)\end{array}$ \\
\hline 13._at & $\begin{array}{l}-0.00806 \\
(0.0424)\end{array}$ \\
\hline 14._at & $\begin{array}{l}0.0268 \\
(0.0235)\end{array}$ \\
\hline 15._at & $\begin{array}{l}0.0514 * * * \\
(0.0175)\end{array}$ \\
\hline 16._at & $\begin{array}{l}0.0679 * * * \\
(0.0189)\end{array}$ \\
\hline 17._at & $\begin{array}{l}0.0783 * * * \\
(0.0222)\end{array}$ \\
\hline 18._at & $\begin{array}{l}0.0840 * * * \\
(0.0257)\end{array}$ \\
\hline 19._at & $\begin{array}{l}0.0419 * \\
(0.0243)\end{array}$ \\
\hline 20._at & $\begin{array}{l}0.0544 * * * \\
(0.0157)\end{array}$ \\
\hline 21. at & $0.0640 * * *$ \\
\hline
\end{tabular}




\begin{tabular}{|c|c|}
\hline 22._at & $\begin{array}{l}0.0711 * * * \\
(0.0115)\end{array}$ \\
\hline 23._at & $\begin{array}{l}0.0761 * * * \\
(0.0139)\end{array}$ \\
\hline 24._at & $\begin{array}{l}0.0794 * * * \\
(0.0165)\end{array}$ \\
\hline 25._at & $\begin{array}{l}0.0684 * * * \\
(0.0141)\end{array}$ \\
\hline 26._at & $\begin{array}{l}0.0595 * * * \\
(0.0105)\end{array}$ \\
\hline 27._at & $\begin{array}{l}0.0515 * * * \\
(0.00940)\end{array}$ \\
\hline 28._at & $\begin{array}{l}0.0443 * * * \\
(0.0105)\end{array}$ \\
\hline 29._at & $\begin{array}{l}0.0377 * * * \\
(0.0126)\end{array}$ \\
\hline 30._at & $\begin{array}{l}0.0319 * * \\
(0.0151)\end{array}$ \\
\hline 31._at & $\begin{array}{l}0.0414 * * * \\
(0.0139)\end{array}$ \\
\hline 32._at & $\begin{array}{l}0.0308 * * * \\
(0.0109)\end{array}$ \\
\hline 33._at & $\begin{array}{l}0.0209 * \\
(0.0120)\end{array}$ \\
\hline 34._at & $\begin{array}{l}0.0119 \\
(0.0157)\end{array}$ \\
\hline 35._at & $\begin{array}{l}0.00356 \\
(0.0202)\end{array}$ \\
\hline 36._at & $\begin{array}{l}-0.00408 \\
(0.0247)\end{array}$ \\
\hline 37._at & $\begin{array}{l}-0.00954 \\
(0.0174)\end{array}$ \\
\hline 38._at & $\begin{array}{l}-0.00682 \\
(0.0152)\end{array}$ \\
\hline 39._at & $\begin{array}{l}-0.00428 \\
(0.0216)\end{array}$ \\
\hline 40._at & $\begin{array}{l}-0.00192 \\
(0.0306)\end{array}$ \\
\hline 41._at & $\begin{array}{l}0.000268 \\
(0.0398)\end{array}$ \\
\hline 42._at & $\begin{array}{l}0.00230 \\
(0.0485)\end{array}$ \\
\hline 43._at & $\begin{array}{l}-0.0374 \\
(0.0291)\end{array}$ \\
\hline 44._at & -0.0240 \\
\hline
\end{tabular}




$\begin{array}{ll}\text { 45._at } & \begin{array}{l}(0.0208) \\ -0.0119 \\ (0.0249)\end{array} \\ \text { 46._at } & -0.000769 \\ & (0.0335) \\ & 0.00930 \\ & (0.0425) \\ \text { 47._at } & 0.0184 \\ & (0.0510) \\ \text { 48._at } & -0.0330 \\ & (0.0323) \\ \text { 49._at } & -0.0197 \\ & (0.0189) \\ \text { 50._at } & -0.00821 \\ & (0.0176) \\ \text { 51._at } & 0.00173 \\ & (0.0215) \\ \text { 52._at } & 0.0102 \\ & (0.0266) \\ \text { 53._at } & 0.0175 \\ \text { 54._at } & (0.0329)\end{array}$

Standard errors in parentheses

Observations $\quad 21,016$

$* * * \mathrm{p}<0.01, * * \mathrm{p}<0.05, * \mathrm{p}<0.1$

Table 4: Marginal effects for three-way interaction. 
VARIABLES

Total FIPs

(Controls not listed)

Property Values (log)

$-31.17 * * *$

(12.06)

$-15.26^{* *}$

(6.228)

Property x GINI

$1.328 * * *$

$(0.511)$

GINI x GINI

$0.159^{* *}$

$(0.0661)$

Property x GINI x GINI

$-0.0139 * *$

(0.00543)

Racial Herfindahl-Hirschman Index

$-5.578 * *$

(2.277)

Property x HHI

$0.467^{* *}$

$(0.189)$

GINI x HHI

$0.230^{* *}$

(0.0981)

Property x GINI x HHI

$-0.0193^{* *}$

(0.00814)

GINI x GINI x HHI

$-0.00235^{* *}$

(0.00106)

Property x GINI x GINI x HHI

$0.000198 * *$

(8.78e-05)

Constant

$351.7^{* *}$

(146.8)

Dispersion parameter

$-0.594 * * *$

(0.0598)

Observations

21,016 
Robust standard errors in parentheses

$* * * \mathrm{p}<0.01, * * \mathrm{p}<0.05,{ }^{*} \mathrm{p}<0.1$

Table 5: Marginal effects output for three-way interaction 


\section{$\underline{\text { Figures }}$}

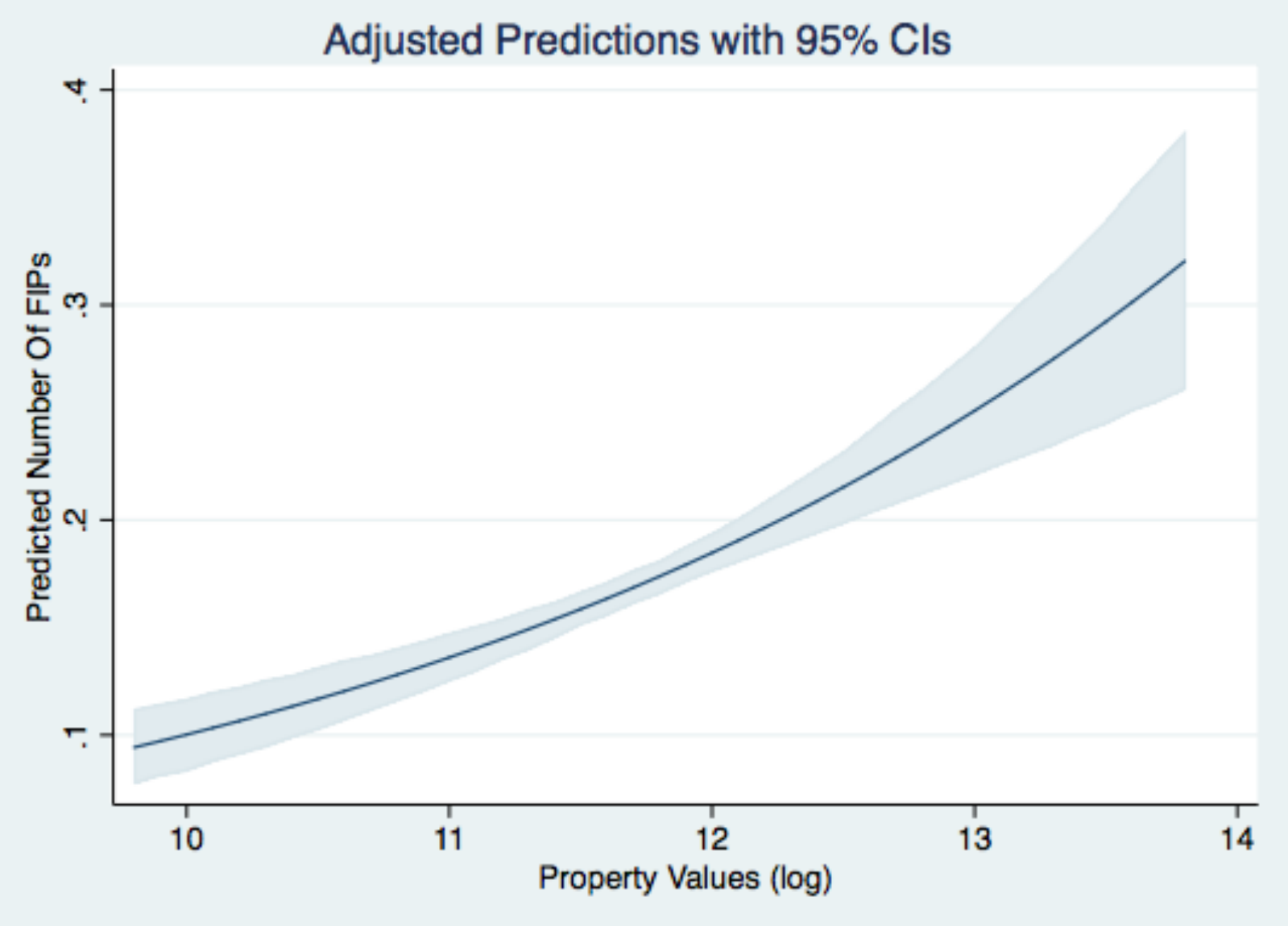

Fig. 1: Effect of property values on FIPs. 


\section{Adjusted Predictions with $95 \% \mathrm{Cls}$}

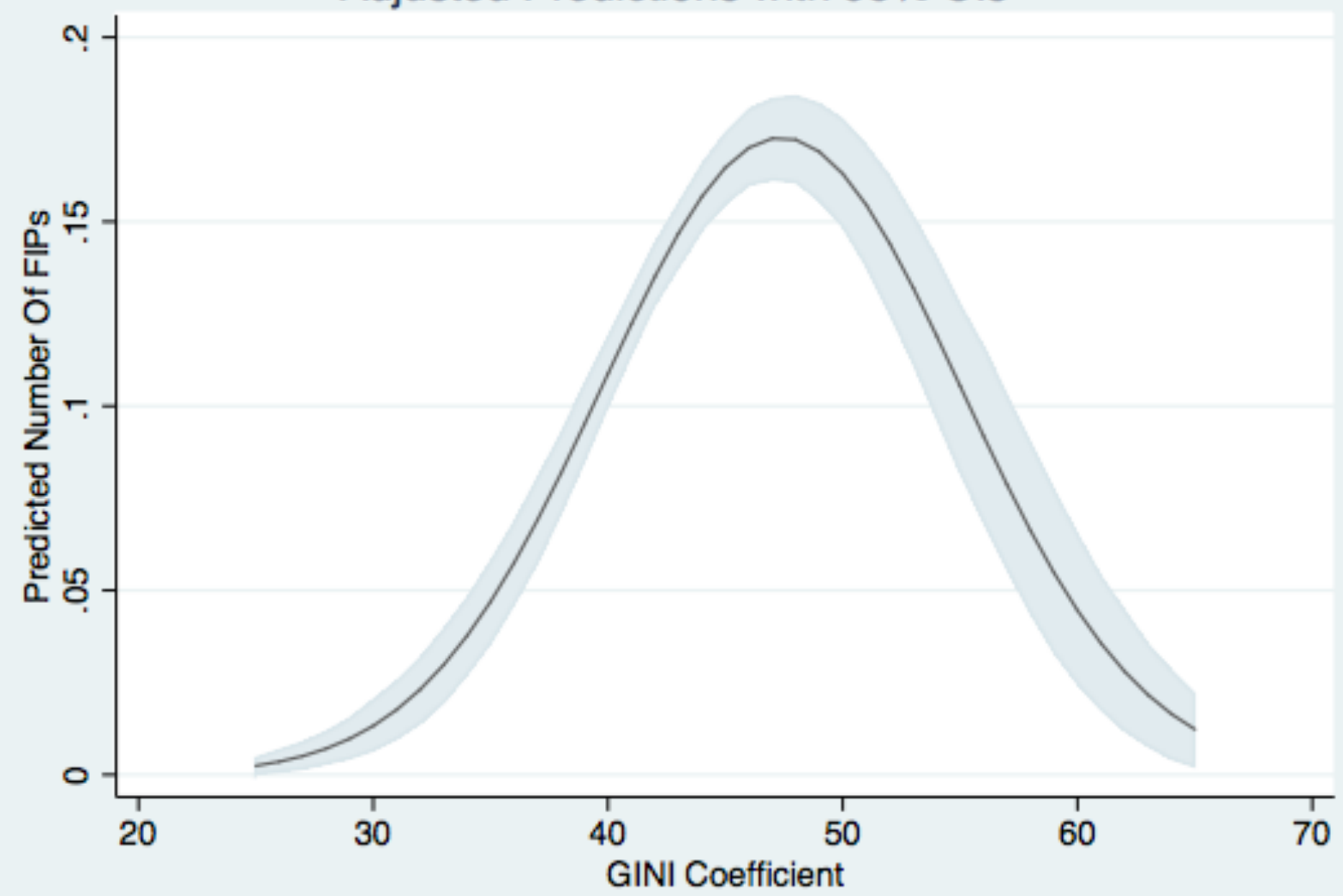

Fig. 2: Effect of GINI coefficient on FIPs. 


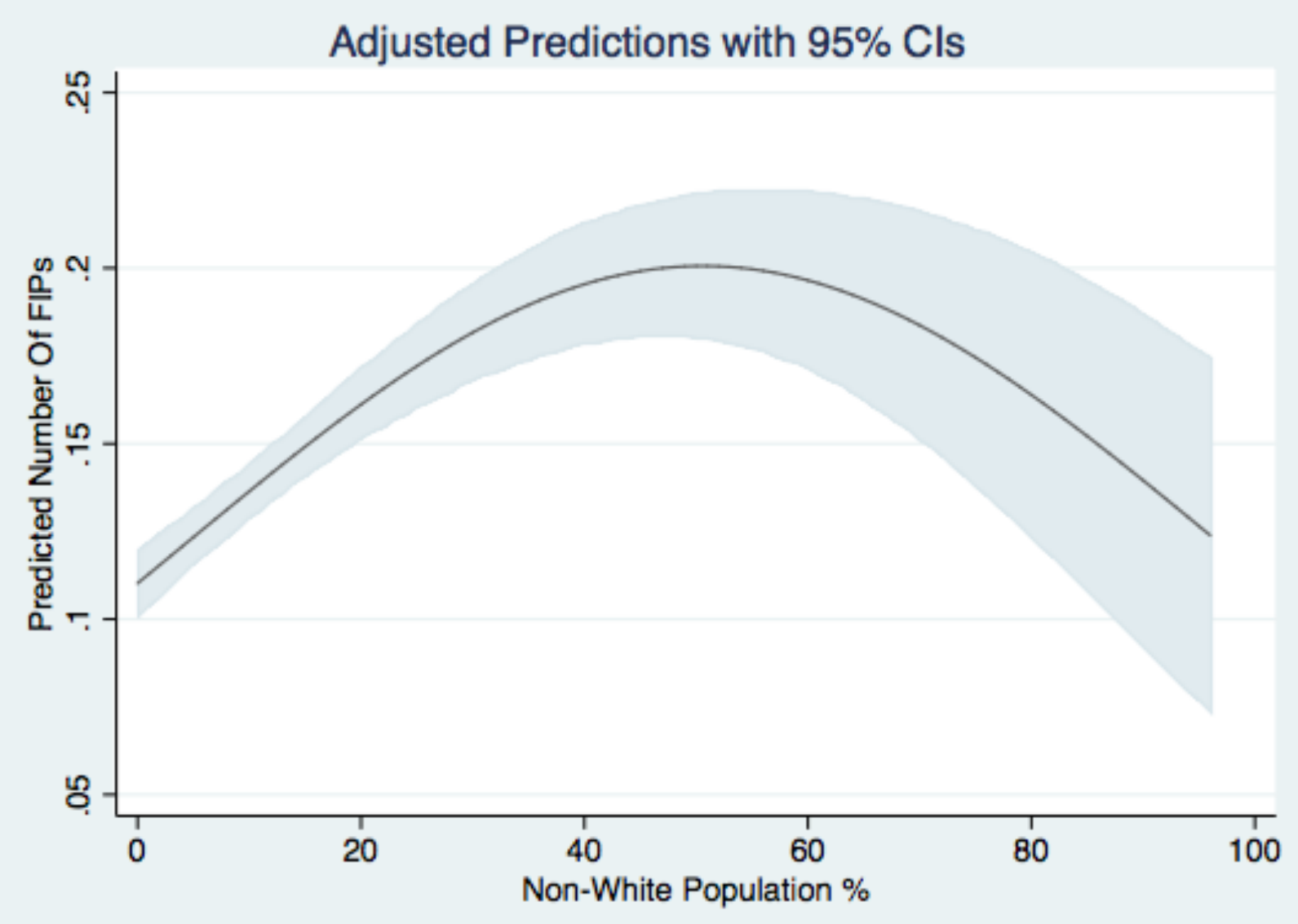

Fig. 3: Effect of non-white population on FIPs. 


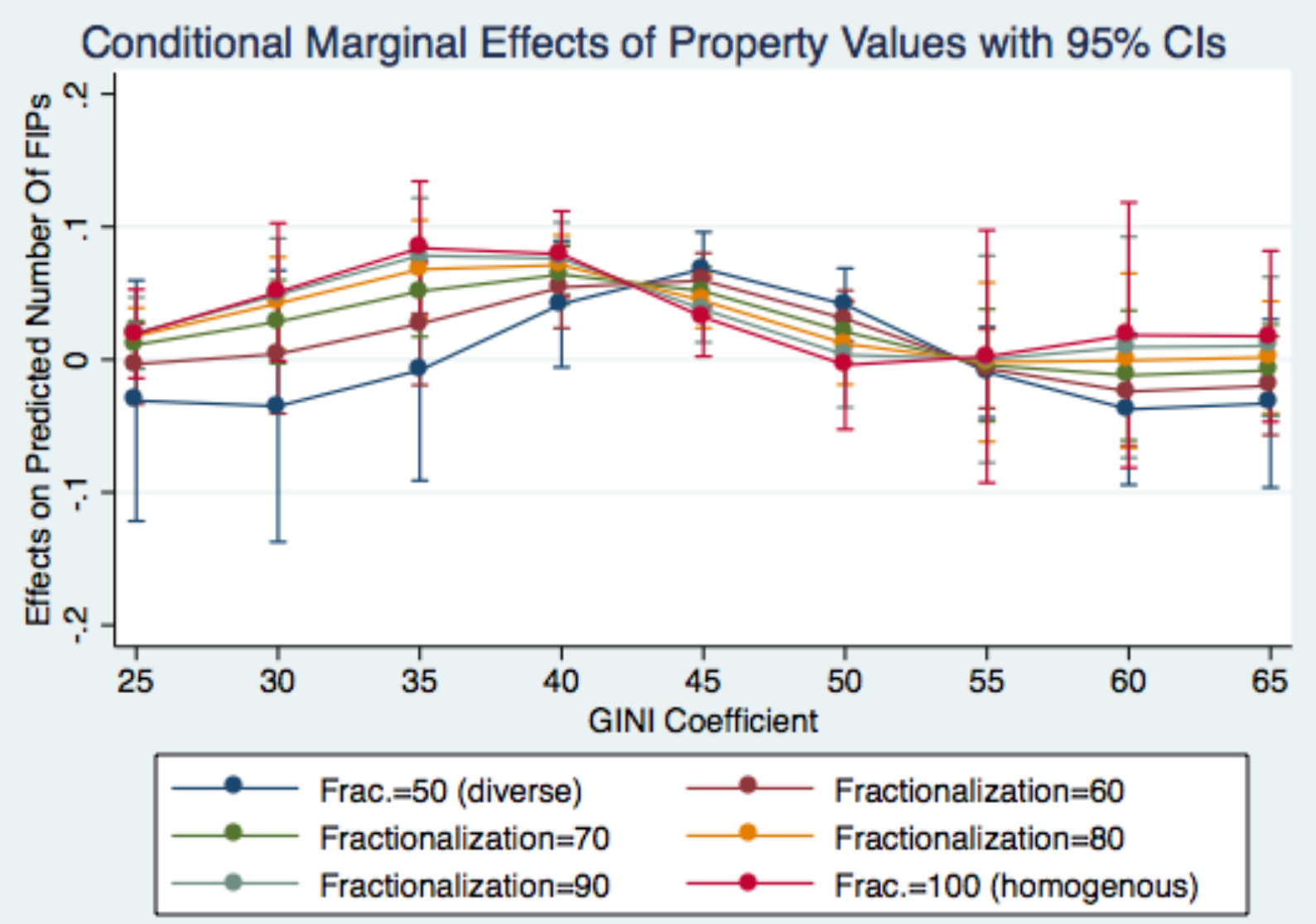

Fig. 4: Three-way interaction 


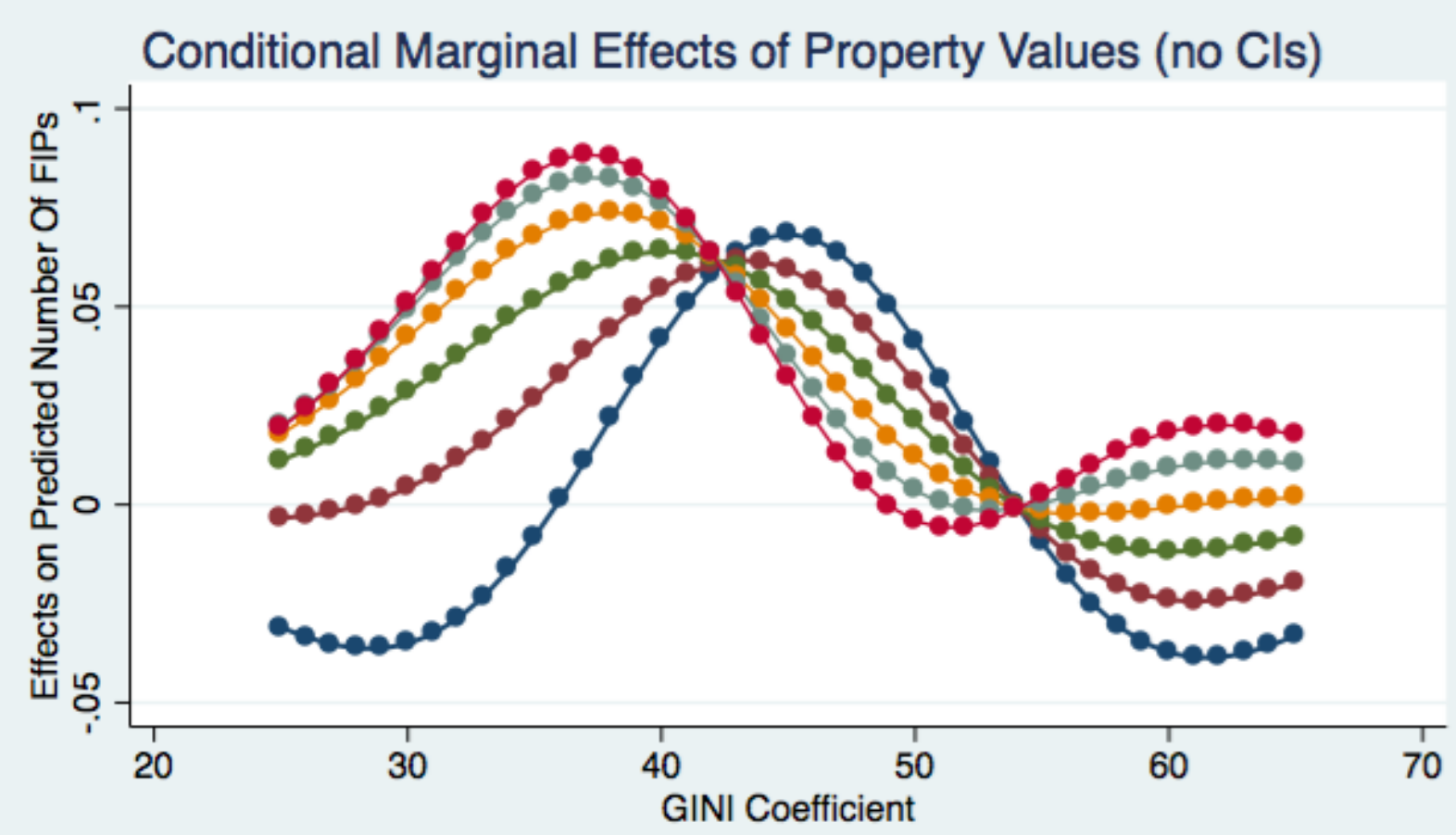

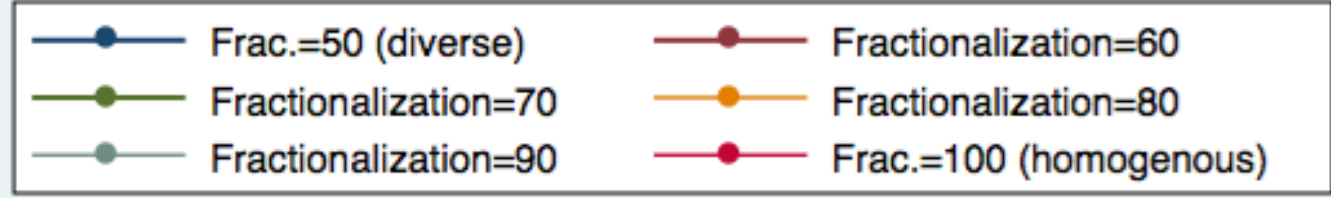

Fig. 5: Three-way interaction, no confidence intervals 


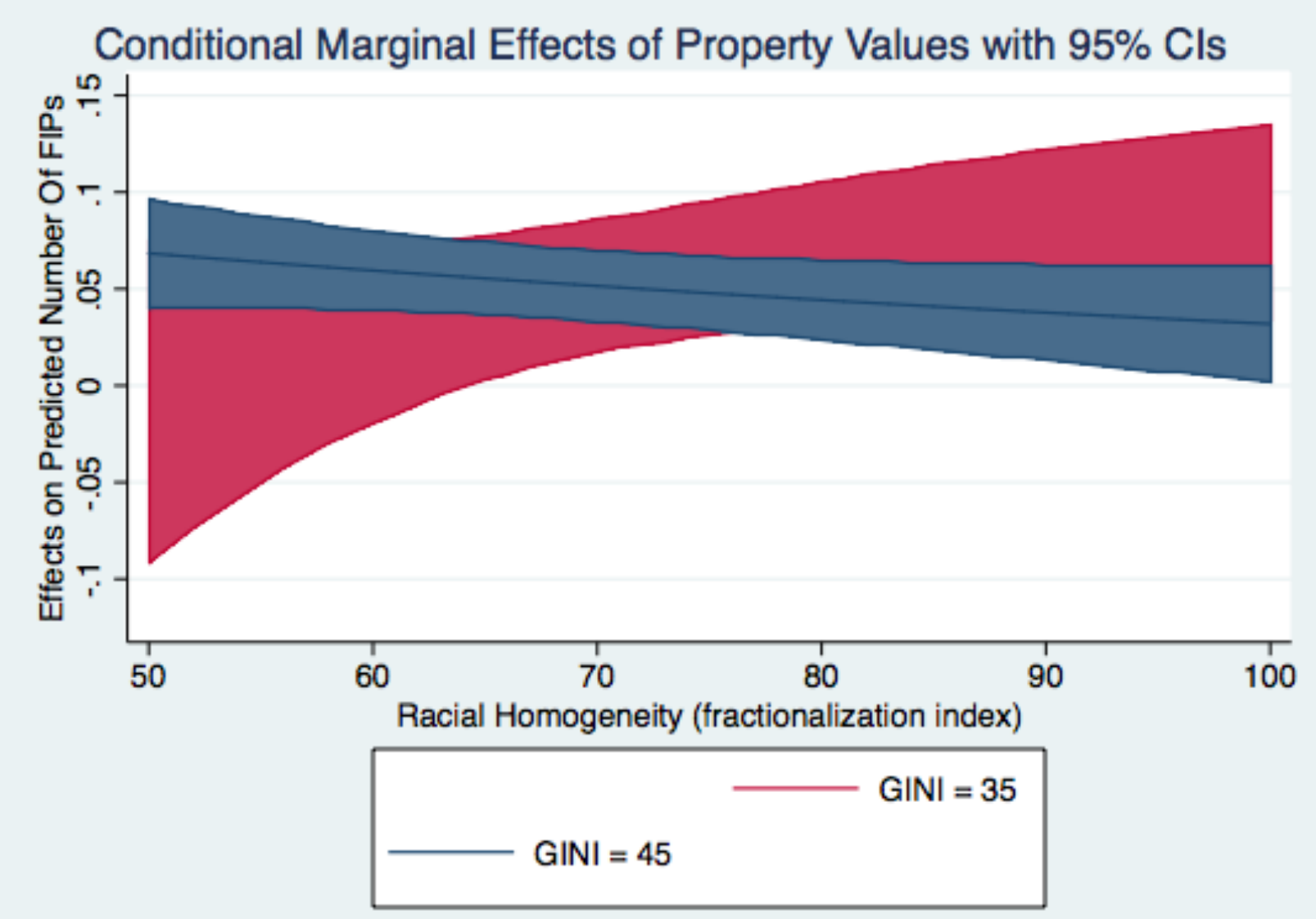

Fig. 6: Comparison of three way interaction separated by levels of inequality 